\title{
EDUCATIONAL MISMATCH AND NON-COGNITIVE SKILLS OF WOMAN ON BOARD IN THE CREATIVE INDUSTRY: A LITERATURE REVIEW
}

\author{
Nur Ika Effendi ${ }^{1}$ \\ Faculty Economic, University of Muara Bungo, Indonesia \\ (Email: yumeika0711@gmail.com) \\ Yanti Murni2 \\ Faculty Economic, Sekolah Tinggi Ilmu Ekonomi Sumbar, Indonesia \\ (Email: yantimurni07@gmail.com) \\ Yessi Gusteti ${ }^{3}$ \\ Faculty Economic, University of Dharmas Indonesia \\ (Email: ygusteti@gmail.com) \\ Khairun A. Roni ${ }^{4}$ \\ Faculty Economic, University of Muara Bungo, Indonesia \\ (Email: khairun_aroni@yahoo.com)
}

Accepted date: $27-01-2019$

Published date: 08-07-2019

To cite this document: Effendi, N. I., Murni, Y., Gusteti, Y., \& Roni, K. A. (2019). Educational Mismatch and Non-Cognitive Skills of Woman on Board in The Creative Industry: A Literature Review. International Journal of Modern Trends in Social Sciences, 2(8), 32-41.

DOI: $10.35631 /$ IJMTSS.28004

\begin{abstract}
Productivity and wages can be motivated by education, skills and experience. This paper is literature study of woman on boards in the creative industry with a focus on interrelationship educational mismatch and non-cognitive skills to strategic decision making in the sustainability of the business they lead. The method used is to examine some the results of previous studies. The findings of this study inform that educational mismatch and noncognitive skills can influence the strategic decisions and more positively affect to cognitive conflict. The limitation of this research is study only conducted at creative industry and only focuses on woman on board. Further qualitative and quantitative research of male and female workers in other types of industries is required to investigate application of such recommendations.
\end{abstract}

Keywords: Educational Mismatch, Non Cognitive Skills, Woman on Board, Strategic Decision, Creative Industry

\section{Introduction}

Economists have long recognized the important role of formal education and cognitive skills in labor market participation and wages since the Becker (1964) and Mincer (1974) studies. In general, schools or formal education can increase workers' wages only if they produce skills that have a rate of return on the labor market (Hanushek, 2002). This is especially in developing 
countries such as mathematical analysis and scientific (Hanushek and Woessman, 2008; Das \& Zajonc, 2010; Singh, 2016).

Based on previous research related to the supply of labor markets and the demand side found that there was an mismatch education in developed countries (McGuinness, 2006). The literature that examines the economic impact of mismatch educational has been investigated by Duncan and Hoffman (1981), where there is a difference level of education achievement by individuals and the work they do.

Previous research has emphasized that IQ and cognitive measures have a major influence on the productivity of high-skilled workers or also affect more educated workers, so non-cognitive skills play a more important role in the entire spectrum of workers (Almlund et al., 2011), especially for workers who under normal wages (Lindqvist and Vestman, 2011). However, the study of Lindqvist and Vestman (2011) found that a standard increase in non-cognitive skills for workers could increase wages by 4\% - 8\%. Likewise Heckman, Stixrud, and Urzua (2006) also estimate that non-cognitive skills can increase workers' wages by $11.2 \%$ from increasing latent non-cognitive skills in the US. This can mean that non-cognitive skills can predict adult wages. However, when viewed from the research of Heckman et al. (2011), found that noncognitive skills greatly predicted educational attainment but had little influence on wages.

The emergence of the industrial revolution era 4.0 with employment opportunities could be a great opportunity to increase women's wages. Why are women? Because, the study of gender diversity is very broad to be studied (Torchia, Calabrò, Gabaldon, \& Kanadli, 2018). Research Eagly, (2016) found the effect of gender diversity in leadership tasks and strategic decision making. Other studies have found that a woman's leader can influence strategic decision making besides that women on board can have influences that can trigger biased cognitive decisions such as processes in information and decision making (Kanadli, Torchia, \& Gabaldon, 2017).

This paper is important to do, given the changes in the era of disruption, which are basically strategic changes in the aspects of business fundamentals (Kasali, 2017). Employment disparities are related to productivity, work quality, gender, and inequality. For this reason, it is very important to discuss the role of women on board creative industry in the face of change in this era, especially when many women work to increase family income, so the domain era disrupts the implications that business management is no longer centered on individual ownership but shares role, Kasali (2017). Why we must discuss creative industry? because the industrial revolution did not interfere with labor-intensive industries.

This study is a literature survey that discusses the relationship between female workers by looking at missmatch education and non cognitive skills in making strategic decisions in the companies they lead. This survey is important as an input for corporate sustainability studies especially if women play an important role in making decisions.

Systematically, this paper will begin with a description of the educational background and noncognitive skills, how to measure them, and various forms of influence on woman on board decision making in the creative industry. This paper aim can help provide what information has been found from the results of previous studies. In addition, information for researchers who are interested in gender issues, woman on board with entrepreneurial skills and their relationship as decision makers. In addition, this research is useful in determining the direction of future research that has not been achieved. This paper has differences from various previous 
writings, because researchers want to include elements of the Islamic approach beyond the conventional approach that has been revealed in previous research.

\section{Educational Mismatch}

Qualification requirements refer to the educational mismatch with requirements from employers, (Heijke, Meng, Ris, 2002). To compare worker qualifications and qualification requirements for employment, there are four qualification categories that can be carried out obtained from the PIAAC (Programme or the International Assesment of Adult Competencies) survey. The level of formal education is based on the ISCED 97 classification namely basic education, secondary education without school leave examinations, secondary education with school leave and higher education. Three alternative categories can then be distinguished, i.e. over education (over qualification), undereducation (under qualification) dan educational match (qualification match). (Rašovec \& Varivnova, 2014)

While research from Chevalier (2003) distinguishes educational mismatch between "too high" workers in the sense of having a higher level of education for their work but showing the same skills as those who are well educated by their coworkers. In addition, he also saw the difference over-education workers, namely workers who were actually paid low in the workplace. The study of Allen and Van der Velden (2001) also discusses differences in human capital from each individual to achieve the same level of education and analyze the level of educational incompatibility with incompatibility in skills.

From a different perspective, the job competition model (Thurow, 1975) assumes that the characteristics of employment determine wages because most of the skills of workers are obtained at work and not through formal education. In the same vein, signaling theory (Spence, 1973) shows that individuals invest in education to tell their abilities to prospective leaders where they will work. Finally, assignment theory (Sattinger, 1993) takes into account the supply side and demand side of the labor market, with wages determined by both parties in the work or the productive characteristics of each individual. The empirical analysis of these theories is based on the framework proposed by Mincer (1974), with estimates of wage equations relating to each individual's school years and their experiences according to their income in mathematical equations.

Based on the previous study, education mismatch is a description of the formal education background of a worker which is sometimes different from what is needed by the employer and this can provide qualifications that can be more than expected or not. There are three distinct categories of alternatives for this variable, which are over education (over qualification), undereducation (under qualification) dan educational match (qualification match). And there are four levels of education, namely basic education, secondary education without school leave, secondary education with school leave and higher education.

\section{Non Cognitive Skill}

Non-cognitive skills can be defined as forms in thoughts, feelings, and behaviors that can influence social interaction with others (Borghans, et. Al., 2008). Recent social scientists have also begun to recognize the important role of personality traits, or non-cognitive skills in determining work productivity. In the study of Cunningham and Villaseñor, (2014) which reviewed 28 surveys of workers in various countries, found that social emotional skills were at the top priority of $76.5 \%$. White, (2013) found that social skills are based on ratings of employee ability preferences. In addition, efforts to improve skills can be done by increasing 
worker programs for some developing countries, especially in Latin America (World Bank 2010).

By improving soft skills, it is expected that each employee will be able to work optimally and get the wages that are obtained as expected (Mateos Romero, Murillo Huertas, \& Salinas Jiménez, 2017). Other studies show an indirect relationship between education and skills of workers, Pietro and Urwin, (2006; Green and McIntosh, (2007). Other researchers found differences in educational background with their expertise (Hillman et al., 2002; Singh et al. ., 2008; van der Walt \& Ingley, 2003; Westphal and Milton, 2000).

From various research results, it can be concluded that non cognitive skills are also needed in the world of work because it can affect worker productivity. In industry 4.0, the millennial generation needs to improve non-cognitive skills, the ability to continue to learn and adapt to changes in the environment, so that the skills of workers are in accordance with existing needs. Especially nowadays skills must be related to mastery of computer technology, communication skills, and the development of the ability to collaborate collaboratively (high level four skills CS / HOSC4C / Creativity, critical thinking, Communication and Collaboration,(Siswanto, Sudira, \& Suyanto, n.d.).

\section{Woman on Board}

Selby, 2000; Eagly, (2016) sees that women with unique values. Woman on Board can be interpreted as a woman who occupies a position of strategic decision making and has the nature of leadership through professional development, Eagly, (2005). In a researcher meeting in Brussels on April 11, 2018 with the theme "All on Board - Closing the Digital Gap for Women and Girls in Developing Countries", it was stated that technology in industry 4.0 could improve women's welfare.

Based on the behavioral approach, gender diversity can be seen from a demographic perspective both in terms of differences in education and in the acceptance of information. When viewed from the existence of woman on board among male workers, a woman who occupies a woman on board position will be different in her behavior and how to make decisions (Bilimoria \& Wheeler, 2000; Eagly, 2005).

Based on the results of the opinions of several experts, it can be seen that women can be women on board, occupy top leadership even though they have unique things and have different educational backgrounds and expertise than their positions.

\section{Creative Industry}

From the study of the Ministry of Trade of the Republic of Indonesia in 2017, the main obstacles faced by creative resources in Indonesia are: (1) the context of artistic creativity in the era of the creative industry has not been comprehensively understood and populist; (2) nonartistic based creativity (science and technology) which is understood to be too microscopic in seeing its profession so that it is too mechanistic and less innovative. Human resources prefer to work in large companies that tend to sink into daily routines; (3) Experimental and expression facilities are still very lacking so that the results of his work become less creative and less innovative. For this reason, it is very important for workers to improve updated and innovative skills, given that competition is increasingly sharp in this industrial era 4.0.

Creative economy is the creation of added value based on ideas born of the creativity of human resources (creative people) and science-based, including cultural heritage and technology 
(Hidayat, 2016). creative economy consists of core creative Industri, forward and backward linkage creative Industri (kemenparekraf, 2014). Indonesia classifies creative industries into 15 sub-sectors, namely: (1) architecture; (2) design; (3) film, video and photography; (4) culinary; (5) crafts; (6) mode; (7) music; (8) approval; (9) interactive games; (10) advertisements; (11) research and development; (12) fine arts; (13) performing arts; (14) information technology; and (15) television and radio, (RAJM Creative Economy, 2014)

\section{Models of research Educational Mismatch and Non-Cognitive Skills of Woman on Board in The Creative Industry}

According to the study of Kanadli, Torchia, \& Gabaldon, 2017) the first is that gender diversity follows women's participation (boardrooms worldwide), and especially in Europe, and the results are the same as increasing the number of women on boards (quota laws in Italy, Spain, Iceland, France, Germany, and EU target di tahun 2020). The second is how competent women leaders can influence a company. This study uses a sample of 317 companies in Norway. Where the result is that attaining critical mas-going from one or two women (few tokens) to a minimum of three women (consistent minority) makes an increase in the level of innovation of the company. This is in line with the research Huse \& Solberg, (2006); Post \& Byron, (2015) that gender diversity will also be in line with firm level outcomes (Finkelstein, Hambrick, \& Cannella, 2009; Johnson, Schnatterly, Hill, 2013). Laud and Johnson (2012), Bredin dan Söderlund (2013) have limited understanding of career strategies by gender and industry.

The research Cyert, March, \& Clarkson, (1963) see the side "the behavioral theory of the firm", where this theory is recognized as the main perspective for understanding organizational behavior and decision making (Argote \& Greve, 2007; Van Ees, Gabrielsson, \& Huse, 2009), (Nielsen \& Huse, 2010). There are three dimensions used by women on the board : including structural, cultural and action, and project-based organizations.

In addition, the research Hillman, Canella, \& Harris, (2002) notice different human capital found the indicator is knowledge, experience, and perspectives. In addition Eagly, (2005) uses values and views in the dimensions of his research, while the results of his research are that women make a difference to their business partners whose gender is different. Women on board positions will have a more positive influence on cognitive conflict. Other views show that there are mixed results from the existence of gender diversity, such as better corporate performance by making variables in their research with moderating and intervention variables (Eagly, 2016; Post \& Byron, 2015). Another study that connects the woman on board mechanism to important company decision making (Husse, Gabrielsson, \& Minichilli, 2009; Huse \& Solberg, 2006; Nielsen et al., 2010; Singh, Terjesen, \& Vinnicombe, 2008), including strategic decisions (Nielsen \& Huse, 2010; Westphal \& Milton, 2000). For this reason, in explaining the contribution to the behavioral approach.

In addition there is also a research model by looking at the perspective of an organization's behavior and decision making (Argote \& Greve, 2007; Van Ees et al., 2009), although empirically adapting the types of companies they lead (Miller \& Triana, 2009). The behavior theory of companies builds the key to success: bounded rationality, satisficing, problemistic search, the routinization of decision making in standard operating procedures, and the dominant coalition (Argote \& Greve, 2007).

In addition, there are also models to minimize and even negate the main constraints faced by Indonesia's creative resources. It is important to develop a vocational training model to support the growth of the creative industry. Based on the analysis of the above constraints, the 
development of Indonesia's resource capacity in the creative industry is not enough only on hand-on skills. Development in vocational and professional fields in the creative industry requires Higher Order Skills Four C (HOS4C) yaitu: (1) Creativity, (2) Critical thinking, (3) Communication, (4) Collaboration (Chinien \& Sigh, 2009; Wagner, 2008; Lucas, Spencer, \& Claxton (2012).

Furthermore there is a model with non-monetary comparative analysis of competencies and educational incompatibility with differences in three different job satisfaction: satisfaction with overall work (SOJ), with type of work (STJ), and with income earned (SW). Each is included as the dependent variable in the following three distributions:

$$
\begin{gathered}
Y_{i}=\Lambda\left(\beta_{0}+\beta_{1} \text { Year_School }_{i}+\beta_{2} O C_{i}+\beta_{3} U C_{i}+\beta^{\prime} X_{i}\right)+\varepsilon_{i} \\
Y_{i}=\Lambda\left(\alpha_{0}+\alpha_{1} \text { Year_School }_{i}+\alpha_{2} O E_{i}+\alpha_{3} U E_{i}+\alpha^{\prime} X_{i}\right)+\mu_{i} \\
Y_{i}=\Lambda\left(\delta_{0}+\delta_{1} \text { Year_Req }_{i}+\delta_{2} \text { Year_OE }_{-} \text {OE }_{i}+\delta_{3} \text { Year_UE }_{i}+\delta^{\prime} X_{i}\right)+\pi_{i}
\end{gathered}
$$

Research (Badillo Amador, Lopez Nicolas, \& Vila, 2008) see undereducation (under qualification) equation (1), date education (datequalification) in equation (2) and equation (3) is overeducation (overqualification). Educational incompatibility has the advantage of being easier to measure and broader in the range of "skills", but also has disadvantages because it is far less precise than skill mismatch.

Based on the theory of human capital, each individual invests their funds in human capital in the present to obtain future benefits from the investment made, either directly or viewed from opportunity costs. The National Earnings specification is:

$$
\mathrm{w}=\mathrm{a} 1 \mathrm{Sa}+\mathrm{X} \mathrm{a} 2+\mathrm{e}
$$

$\mathrm{Sa}$ is the actual years of education attaineod, $\mathrm{X}$ is a vector of control variables dan $\mathrm{e}$ is a random error, split the schooling variable $(\mathrm{Sa})$ years of required education $(\mathrm{Sr})$ and years of surplus (So), deficit (Su), of schooling-years of over-education and under-education dapat ditulis

$$
\mathrm{Sa}=\mathrm{Sr}+\mathrm{So}-\mathrm{Su}
$$

Next:

$$
\ln \mathrm{w}=\beta 0+\beta 1 \mathrm{Sr}+\beta 2 \mathrm{So}+\beta 3 \mathrm{Su}+\mathrm{X} \beta 4+\mathrm{e} \text { (Badillo Amador et al., 2008) }
$$

Similarly, research in ten countries in Europe analyzed the economic impact of education by estimating the different specifications of the HOS4C model which consists of two models, not only taking into account the education year but also the level of skills actually obtained by individuals in the creative industry (Mateos Romero et al., 2017). The results of his research are grouping labor in more homogeneous blocks (Nordic, Mediterranean, Continental, and Eastern Blocks). In the research procedure the development of the HOS4C model was divided into 3 groups of activities, namely pre-development, development and implementation of the operational model outlined in the following description:

1. The Pre-Development Phase, information is collected about the implementation of the improvement program

2. In addition, it also examines the scope of the product (fostering workplace-based SDI / WBL), the extent of use and supporting conditions, 
3. In the conceptual development phase, the direction of developing the HOS4C model that supports the creative industry is formulated based on needs

4. In the model implementation phase, the development of the HOS4C model that supports the workplace-based creative industry is a theoretical or semi-perfect prototype model that will be further developed.

Based on the HOS4C prototype model, the support of the workplace-based creative industry is equipped with a review assessment instrument from other parties involved in the development, users of the HOS4C model supporting the workplace-based reative industry, management support, and then results are made. Development procedure in Figure 1 below (Siswanto et al., n.d., 2013)

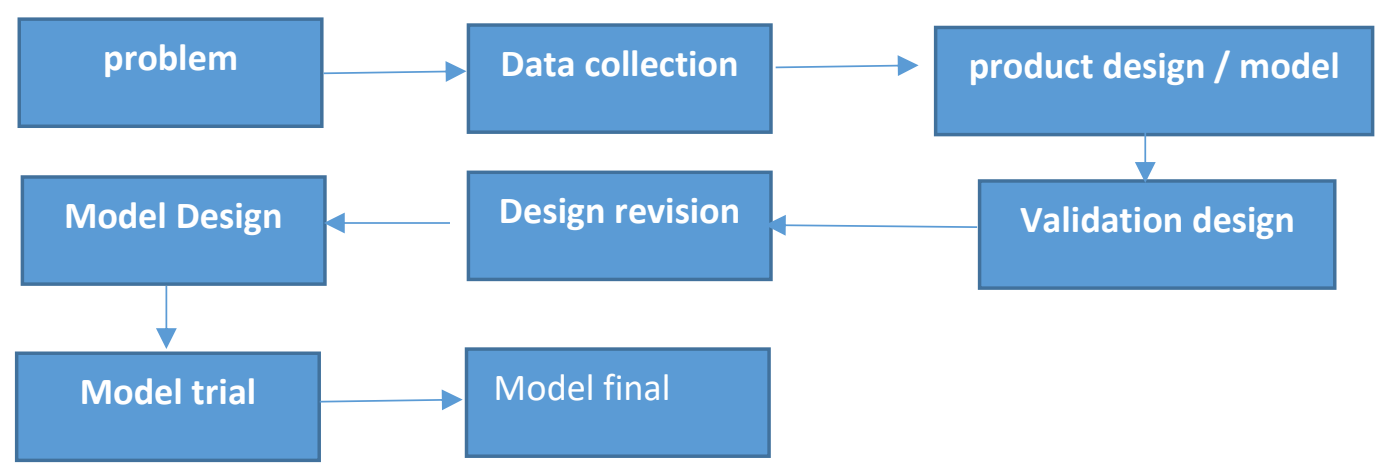

Figure 1: Model Development Procedures

Research Siswanto et al., (2013) in figure 1 Model Development Procedures model I we can saw a direct relationship between woman on board (ratio) and the level of organizational innovation. This research is in line with the research of Baron \& Kenny, (1986). Furthermore, in model II looks at the ratio of women to organizational innovation. Whereas model III looks at cognitive mediation conflicts with respect to the relationship of independent variables and dependent variables (organizational innovation) or full mediation or partial mediation. The results of his research turned out that the ability of woman on board to develop and improve labor could be well trained. The suggested scheme for developing $4 \mathrm{C}$ soft skills can be seen in Figure 2.

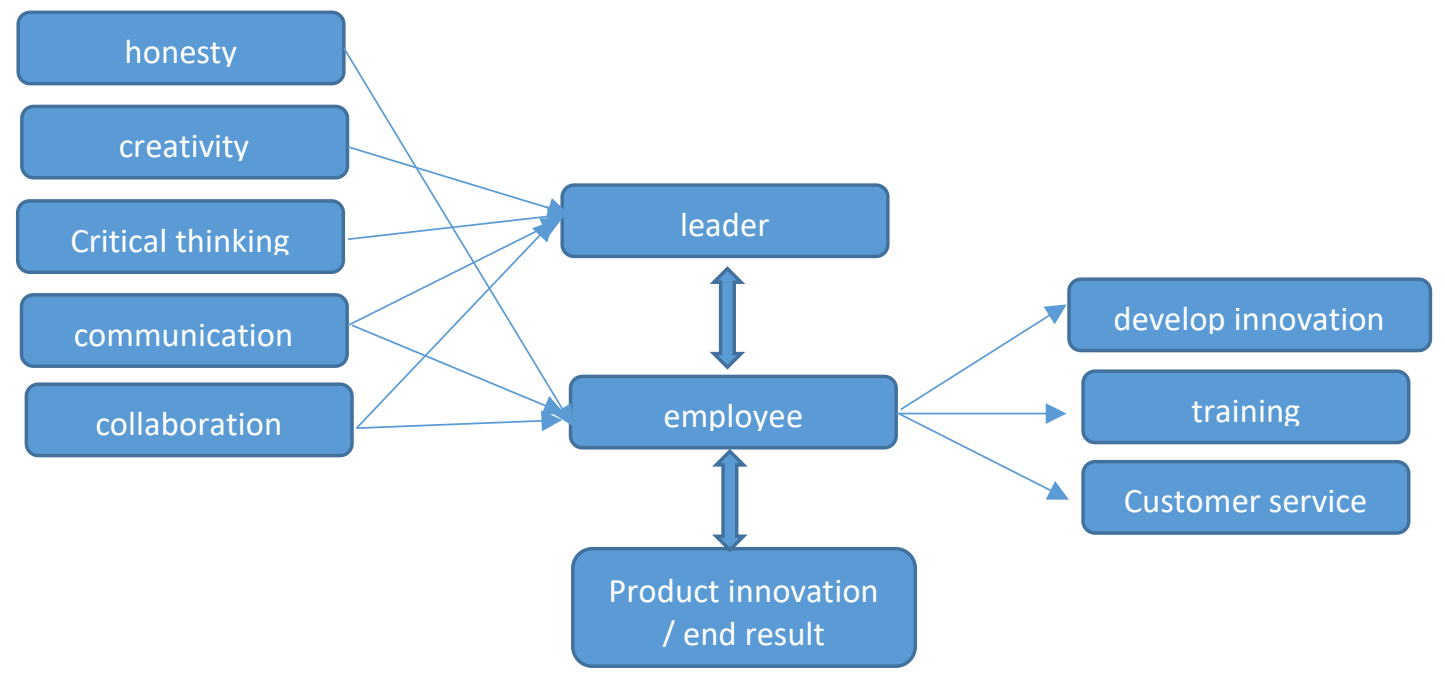

Figure 2: Soft Skill Development Scheme in The Creative Industry 
In figure 2 Soft Skill Development Scheme in The Creative Industry we can see scheme for developing $4 \mathrm{C}$ soft skills with respect to the relationship of independent variables and dependent variables (organizational innovation).

\section{Conclusion and Discussion}

The definition, size and problem of women on the board in the creative industry is very diverse. This is related to individuals who are always changing and developing. It is hoped that further research can discuss women's workers qualitatively and quantitatively or discuss male workers who work outside the creative industry sector using multivariates such as discriminant analysis, factor analysis, SEM or with other assistance so that they will be shown, among others : (1) The woman on board development model framework in creative industries in Indonesia (2) The empirical model of educational mismatch and non cognitive skill woman on board in the creative industry so as to develop high-order skills in the form of creativity, critical thinking skills, communication skills, and the ability to collaborate and build networks with people from various disciplines and skills as well as from various cultural and traditional backgrounds; (3) The empirical model of how to deal with the educational mismatch and non-cognitive skills of female workers who occupy the top positions can make decisions for the companies they lead with the diversity of their workers when viewed from the dimensions bounded rationality, satisficing, problemistic search, the routinization of decision making in standard operating procedures, and the dominant coalition.

\section{References}

Almlund, M., A. Duckworth, J. Heckman, and T. Kautz. (2011). Personality Psychology and Economics, in E. Hanushek, S. Machin, and L. Woessman, eds., Handbook of the American Economic Review, 90(5), 1184-1208.

Argote, L., \& Greve, H. R. (2007). A behavioral theory of the firm-40 years and Acounting:Introduction and impact. Organization Science, 18(3), 337-349.

Badillo Amador, L., Lopez Nicolas, A., \& Vila, L. E. (2008). Education and competence mismatches : job satisfaction consequences for workers. Classification JEL ( Journal of Economic Literature), 1:105(1), 1-12.

Baron, R. M., \& Kenny, D. A. (1986). The moderator-mediator variable distinction in social psychological research: Conceptual, strategic, and statistical considerations. Journal of Personality and Social Psychology, 51(6), 1173-1182.

Becker, G. (1964). Human Capital. New York: Columbia University Press (for National Bureau of Economic Research).

Bilimoria, D., \& Wheeler, J. V. (2000). Women Corporate Directors: Current Research And Future Directions. In M. Davidsson, \& R. J. Burke (Eds.). Women in management: Current research issues (pp. 138-163). London: Paul Chapham.

Bilimoria, D. (2006). The Relationship Between Women Corporate Directors and Women Corporate Officers. Journal of Managerial Issues, 18(8), 17.

Borghans, L., A. Lee Duckworth, J. Heckman and B. ter Weel. (2008). - The Economics and Psychology of Personality Traits. Journal of Human Resources 43(4):972-1059.

Burke, R. (2000). Company size, board size, and the numbers of women corporate directors. In M. Burke, \& R. Mattis (Eds.). Women on corporate boards of directors: International challenges and opportunities (pp. 118-125). Dordrecht, The Netherlands: Kluwer.

Card, D. (2001). - Estimating the Return to Schooling: Progress on Some Persistent Econometric Problems, Econometrica 69(5):1127-1160.

Cyert, R. M., March, J. G., \& Clarkson, G. P. E. (1963). A behavioral theory of the firm (2nd ed.). Oxford: Blackwell. 
Eagly, A. H. (2005). Achieving Relational Authenticity In Leadership: Does Gender Matter? Leadership Quarterly, 16(3), 459-474.

Eagly, A. H. (2016). When Passionate Advocates Meet Research On Diversity, Does The Honest Broker Stand A Chance? Journal of Social Issues, 72(1), 199-222.

Fan, C.K, (2011). A Longitudinal Examination of Children's Emotion Regulation Problems, Negative Parenting Behaviors, and the Development of Internalizing Behavior Problems, PhD dissertation, University of Michigan Growth

Finkelstein, S., Hambrick, D. C., \& Cannella, A. A. (2009). Strategic leadership: Theory and Research On Executives, Top Management Teams, And Boards. New York: Oxford University Press

Gabaldon, P., De Anca, C., Mateos De Cabo, R., \& Gimeno, R. (2016). Searching for women on boards: An analysis from the supply and demand perspective. Corporate Governance: An International Review, 24(3).

Green, D. \& McIntosh, S. (2007): Is There a Genuine Under-utilization of Skills Amongst the Over-qualified?, Applied Economics, 39(4),427-439.

Hanushek, E. \& Kimko, D. (2000): Schooling, Labor Force Quality, and Economic mismatches: Effects on Wages, Job Satisfaction, and On-the-job Search, Oxford Economic Papers, 53(3), 434-452.

Hanushek, E. (2002). - Publicly Provided Educationl, in A. Auerbach and M. Feldstein, eds., Handbook of Public Economics, Volume 4. North Holland Growth

Hanushek, E. \& Woessmann, L. (2008): The Role of Cognitive Skills in Economic Development, Journal of Economic Literature, 46(3), 607-668.

Heckman, J., J. Stixrud, and S. Urzua. (2006). -The Effects of Cognitive and Noncognitive Abilities on Labor Market Outcomes and Social Behavior. Journal of Labor Economics 24(3): 411-82.

Heckman, J., J. E. Humphries, S. Urzua, and G. Veramendi. (2011). The Effects of Educational Choices on Labor Market, Health, and Social Outcomes, mimeo.

Heckman, J. and J. Yi, (2014). - Human Capital, Economic Growth, And Inequality in Chinall, in S. Fan, R. Kanbur, S. Wei, and X. Zhang, eds., The Oxford Companion to the Economics of China. Oxford University Press.

Hillman, A. J., Canella, A. A., \& Harris, I. C. (2002). Women and Racial Minorities In The Boardroom: How do directors differ? Journal of Management.

Hillman, A. J. (2015). Board diversity: Beginning to Unpeel The Onion. Corporate Governance (Oxford), 23(2), 104-107.

Huse, M. (2007). Boards, Governance and Value Creation: The Human Side of Corporate Governance. Cambridge: Cambridge University Press.

Huse, M., \& Solberg, A. G. (2006). Gender-Related Boardroom Dynamics: How Scandinavian Women Make And Can Make Contributions On Corporate Boards. Women In Management Review, 21(2), 113-130.

Huse, M., Gabrielsson, J., \& Minichilli, A. (2009). Improving Corporate Governance Practices. In R. C. C. Burke (Ed.). The Peak Performing Organizations. Routledge.

Huse, M. (2012). The Golden Skirts: Lessons From Norway About Women On Corporate Boards Of Directors. In S. Groschi, \& J. Takagi (Eds.). Diverstiy Quotas, Diverse Perspectives: The Case of Gender (pp. 11-24). Farnham: Glower.

Hidayat, A. S. (2016). Strategi Pengembangan SDM Industri Kreatif Indonesia dalam Menghadapi Masyakarat Ekonomi Asean Pada Tahun. Prosiding Seminar Nasional Indocompac, 6(2), 193-206.

Kanadlı, S. B., Torchia, M., \& Gabaldon, P. (2017). Increasing Women's Contribution on Board Decision Making: The Importance Of Chairperson Leadership Efficacy And Board Openness. European Management Journal, 1-14. 
Lindqvist, E. and R. Vestman.(2011). The Labor Market Returns to Cognitive and Noncognitive Ability: Evidence from the Swedish Enlistment. American Economic Journal: Applied Economics 3: 101-128.

Mateos Romero, L., Murillo Huertas, I. P., \& Salinas Jiménez, M. Del M. (2017). Wage Effects Of Cognitive Skills And Educational Mismatch In Europe. Journal of Policy Modeling, 39(5), 909-927. https://doi.org/10.1016/j.jpolmod.2017.08.001

McIntosh, S. \& Vignoles, A. (2001) Measuring and Assessing the Impact of Basic Skills on Labour Market Outcomes, Oxford Economic Papers, 53(3), 453-481

Miller, T., \& Triana, M. (2009). Demographic Diversity In The Boardroom: Mediators Of The Board Diversity -Firm Performance Relationship Toyah Miller And María Del Carmen triana. Journal of Management Studies, 46(5), 755-786.

Mincer, J. (1974): Schooling, Experience, and Earnings, National Bureau of Economic Research, Columbia University Press, New York.

Minichilli, A., Zattoni, A., \& Zona, F.(2009). Making Boards Effective: An empirical examination of board task performance. British Journal of Management, 20(1), 55-74.

Nielsen, S., \& Huse, M. (2010). Women directors' contribution to board decision making and strategic involvement: The role of equality perception. European Management Review, 7(1), 16-29.

Nielsen, S., Huse, M. (2010). The contribution of women on boards of directors: Going beyond the surface. Corporate Governance, 18(2), 136-148.

Post, C., \& Byron, K. (2015). Women on boards and firm financial performance: A metaanalysis. Academy of Management Journal, 58(5), 1546-1571.

Rašovec, T., \& Varivnova, T. (2014). Skills and Educational Mismatch in the Czech Republic : Comparison of Different Approaches Applied on Piaac Data. Statistika: Statistics and Economic Journal, 94(3), 58-79.

Selby, C. C. (2000). From Male Locker Room To Co-Ed Board Room: A Twenty-five Year Perspective. In R. J. Burke, \& M. C. Mattis (Eds.). Women On Corporate Boards Of Directors: International Challenges And Opportunities (Pp. 239-251). Dordrecht: Kluwer Academic Publishers.

Singh, Abhijeet. (2016). Learning More With Every Year: School Year Productivity and International Learning Divergence, working paper, University College London.

Spence, M. (1973). Job Market Signaling. Quarterly Journal of Economics, 87(3), 355-374.

Siswanto, B. T., Sudira, P., \& Suyanto, W. (n.d.). Pengembangan Higher Order Skills Four CS ( HOS4C ), (2), 1-18.

Torchia, M., Calabrò, A., Gabaldon, P., \& Kanadli, S. B. (2018). Women Directors Contribution To Organizational Innovation: A Behavioral Approach. Scandinavian Journal Of Management, 34(2), 215-224. Https://Doi.Org/10.1016/ J. Scaman.2018. 02.001

Van der Walt, N., \& Ingley, C. (2003). Board Dynamics And The Influence Of Professional Background, Gender And Ethnic Diversity Of Directors. Corporate Governance: AnInternational Review, 11(3), 218-234.

Van Ees, H., Gabrielsson, J., \& Huse, M. (2009). Toward A Behavioral Theory Of Boards And Corporate Governance. Corporate Governance, 17(3), 307-319. 